\title{
Responsiveness of the Zambian mine tax regimes to attributes of 'good tax' criteria
}

\author{
Chisakulo, Edward $₫$ \\ School of Mines \& Mineral Sciences, Copperbelt University, Zambia (eddie.chisakulo@yahoo.com) \\ Kambani, Stephen \\ Mining Engineering Department, University of Zambia, Zambia (skambani@unza.zm)
}

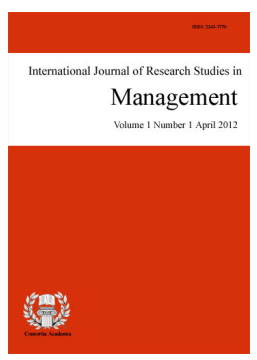

ISSN: $2243-7770$

Online ISSN: 2243-7789

Received: 10 January 2018

Revised: 17 September 2018 DOI: $10.5861 /$ ijrsm.2018.3002

Accepted: 27 October 2018

OPEN ACCESS

\section{Abstract}

Formulation of the fiscal regime for the extractive industry requires meeting the competing needs for both investors and government. Such desires are tackled when government policymakers put in place fiscal regimes that respond to the attributes of the 'good tax' criteria dealing with, among others; stability, equity, progressiveness, transparency and clarity, risk sharing, economic efficiency, neutrality and non-regressiveness. The objective of this study was to assess the responsiveness of the Zambian mine fiscal regimes to the attributes of 'good tax' criteria. The study design was descriptive with data collection employing both questionnaires and semi-structured interviews meant to gather respondents' opinions using Likert items addressing the attributes of 'good tax' criteria. Non-probability purposive sampling was conducted with 82 questionnaire respondents and 13 interviewees from the mining industry. Questionnaire survey findings indicated that $63 \%$ of the respondents disagreed to the Zambian mine tax systems being responsive to the attributes of 'good tax' criteria. Responses from interviewees supported this outcome and signified that the taxation regimes fail to embrace the economic perspective dealing with stability, neutrality, transparency, risk sharing and progressivity. Interviewees felt that weak institutional capacities, policy inconsistencies, information asymmetry, and lack of stabilisation agreements in the fiscal regimes affected the responsiveness of the Zambian mine taxation systems to attributes of 'good tax' criteria.

Keywords: fiscal regime; stabilisation agreement; information asymmetry; institutional capacities; progressivity; policy inconsistency; Zambia 


\section{Responsiveness of the Zambian mine tax regimes to attributes of 'good tax' criteria}

\section{Introduction}

Governments in resource rich countries strive to put in place ideal fiscal regimes for the extractive industry with objectives to secure a flow of revenue through foreign direct investment (FDI). This is done in order to sustain the operations of the resource sectors as well as get reasonable returns from their extractive resources needed for socio-economic development of the countries. Balancing these objectives between the needs of the investors and the government remains a daunting task which requires policy makers to formulate fiscal regimes that favorably respond to the attributes of the 'good tax' criteria.

One of the main ways by which wealth from the mining sector get shared and used to promote growth throughout the economy is through taxation, investment and redistribution of tax revenue (Korinek, 2015). In minerals taxation policy, the aim is to enable governments to collect a reasonable return from the extraction of the community's mineral resources, while ensuring that industry outcomes remain efficient and administrative costs are not excessive (Hogan, 2008). Designing such fiscal regimes also requires that unique characteristics (Calder, 2014; International Council on Mining and Metals [ICMM], 2009; Otto, Andrews, Cawood, Dogget, Guj, et al., 2006) possessed by extractive industry be put into consideration. In most cases, investors seek fiscal regimes that provide certainty for them to forecast their capital investment profiles. To meet these expectations for investors, resource rich governments need to put in place stable, transparent, predicable, risk sharing, equitable and economically efficient taxation systems.

Zambia still has exceptionally high level of macro-economic dependence on mining when compared to international standards. Mining also makes an unusually large contribution to total national investment and to total foreign direct investment when compared to other countries (Zambia Extractive Industries Transparency Initiative, 2014). The national contribution of mining in Zambia for the year 2012 as estimated by ICMM (2014) was $86 \%$ of foreign direct investment (FDI) and $80 \%$ of export earnings. The contribution, however, was progressively low in other macro areas with less than $25 \%$ of government revenue, less than $12 \%$ of GDP and only $1.7 \%$ contribution to gross employment. Mineral taxation is important to both government and mining companies. Andrews-Speed (2000) indicated that taxation to the government presents aspects like raising money to pay for expenditures, promotion of certain social and economic policies, promotion of certain industries, and control of sector development by using it to influence development of certain sectors. To mining companies, taxation is of critical importance because it affects; the profit a company can make, the country a company chooses to invest in, and what sort of projects a company undertakes and how it implements them.

\subsection{Research problem}

For extractive industries, competing priorities for governments and investors remain a challenge to resolve in Zambia and in many other resource rich countries. World Bank (2015) reported for Zambia that the challenge of optimally mobilizing resource revenues requires the government to strike the right balance between encouraging revenue-generating investment and capturing an appropriate share of the resulting revenues. The share of the country's mineral rent is appropriated through mainly taxation. Manley (2013) recounted that since privatization, there has been considerable public debate over how to ensure that an appropriate share of mineral resource revenues accrue to the Government. Mineral Resource Development Policy [MRDP] (2013) highlighted that the sector contributed $9 \%$ to GDP with low tax contribution to the treasury at $1.1 \%$ of the GDP. This was because of the incentives granted to large-scale mining companies through Development Agreements between 1995 and 2008, a measure that resulted in a weak fiscal and regulatory framework.

Africa Progress Report (2013, p. 64) indicated that revenues secured by many resource-rich countries appear 
to be very low in relation to the value of exports, and compared with international standards. In 2011, Zambia's copper exports generated US\$10 billion, while government revenues from copper were only US\$240 million - or $2.4 \%$ of export value. This is a figure which exposes unfair tax regime against resource-rich countries in Africa representing only $2.4 \%$ of the total export value of Zambia's export earnings.

\subsection{Research objectives}

Based on various concerns about low revenues accruing to the state, this paper aims to understand how the Zambian mine fiscal regimes of the post-2000 privatisation period respond to the attributes of 'good tax' criteria. This is achieved through interrogating 'experts' from the various stakeholder groups constituting the Zambian mining industry using the study statements dealing with the Zambian mine fiscal regimes being; stable, progressive, neutral, risk sharing, equitable, transparent, non-regressive and economically efficient. The findings from this descriptive study were used as a basis for making conclusions and recommendation.

\subsection{Significance of the study}

The results of this study have some policy and investment implications in the Zambian mining industry. The study will provide input to economic analysis upon which government and extractive industry can draw in their negotiations of fiscal terms that can offer a fair, stable and just basis of rent capturing based on good taxation criteria from the country's mineral wealth. This study will also add to the existing literature on mineral taxation design and implementation in Zambia by understanding how mining fiscal regimes based on the principles of 'good tax' criteria work in practice. Against this backdrop, the research may serve as a useful reference material for learners and those who want to undertake research on the design of mineral tax systems that will reduce the perceived risk in investment and balance the interests of both parties -government and investors. Since governments apply various taxation systems to capture revenues from mine investment, policymakers need to be adequately enlightened based also on the opinions from the public to make informed decisions on the types and levels of taxation linked to economic perspectives.

\subsection{Scope of the study}

The study focused on the stakeholders in the mining industry of Zambia existing both in the capital city of Zambia, Lusaka and other mining towns on the Copperbelt province. These stakeholder groups comprise extractive companies, government institutions, civil society groups, mine suppliers, various consultants, mineworkers unions and the general communities in mining areas.

\section{Literature reviews}

\subsection{Principles of a 'good tax' criteria}

Many resource rich countries find it difficult to design an ideal taxation regime that responds to 'good tax' criteria under today's competitive conditions that require meeting the differing interests of the two key stakeholders - government and investors. Smith (1776) outlined four principles of an ideal tax system named as 'canons of taxation'. These principles are equity, certainty, convenience and economy. These principles correspondingly noted by Alley and Bentley (2005) are important to the creation of a tax policy and once upheld, effective taxes are implemented in a manner which satisfies the stated purposes of a tax system.

A number of authors (Garnaut \& Ross, 1983; Harman \& Guj, 2013; Kumar, 1991; Nakhle, 2008; Nellen, 2002; Otto \& Cordes, 2002) have categorized fundamental criteria against which any fiscal regime can be evaluated as attractive. These principles, among others, include; stability; equity; progressivity; clarity and simplicity; risk sharing, efficiency; and neutrality. The tax instruments and the tax frameworks are used to assess the performance of the fiscal regime in relation to these attributes of 'good tax' criteria in order to meet the 
competing interests of the two key stakeholders. Baunsgaard (2001) evaluated several fiscal instruments in mineral taxation by employing the ratings approach in order to provide an overview of the advantages and disadvantages of the most common fiscal instruments in the mining sector. These were based on seven criteria dealing with: neutrality; stability; project risk; flexibility; fiscal loss; revenue delay; and administration.

Stability - Guj, Bocoum, Limerick, Meaton, and Maybee (2013) reported that because of the significant up-front capital investments, stability argues that tax liabilities should be predictable and, ideally, stable over the life of the mine before any proposed mining investment takes place. Tissot (2010) argued that royalty/tax based regimes have an intrinsic instability since governments cannot deny future administrations the right to legislate taxation. Natural Resource Charter (2014, p.7) affirmed that stability permits project development and operations to take place in a more efficient and socially responsible manner. However, this is not to say that the regime should be fixed. Both fiscal and contractual regimes need to be subject to modification and have built-in flexibility to reflect changing and uncertain circumstances. Furthermore, Daniel and Sunley (2010) argued that in some countries, governments offer explicit fiscal stability clauses in contracts, promising renegotiations or immunity in the event of future tax increases. One problem is the short lifetime of governments when compared with that of many resource projects. Otto $(2007, \mathrm{p} .27)$ posited that 'tax stabilization has been found to be attractive to companies while many governments are hesitant to use them. The government has a dilemma because on one hand, stabilization agreements enhance the potential for mineral development, and on the other, they complicate the tax system and raise administrative challenges.' Therefore, Minnitt and Cawood (1999) approved that tax regimes should be stable and frequent adjustments avoided as they increase the perceived risk of investment.

Equity - Equity principle is a concept, as indicated by Otto and Cordes (2002), which has been used to encourage taxation based on the ability to pay. It is an issue concerned with whether a tax is fair on taxpayers. Harman and Guj (2013) mentioned that the fairness of equity has a number of dimensions including horizontal equity which implies equal treatment of equals. This queries whether miners generating the same amount of economic rent are paying the same type of tax. By contrast, vertical equity is concerned with whether miners who generate different amount of economic rent are treated differently in the amount of tax they pay. Vertical equity also refers to equivalent treatment of companies or resources with different characteristics (Nakhle, 2008). Implications are that firms that exploit more valuable resources have a greater ability to pay and so their tax liabilities can be greater. Similarly, fields with high profitability can be taxed more heavily than those with low profitability. This is a principle which is more satisfied with a progressive tax.

Progressivity and regressivity - Progressivity means that a tax regime will yield a rising present value of government revenue as the pre-tax rate of return on a project increases (Daniel, Goldsworthy, Maliszewski, Puyo, \& Watson, 2010). Fiscal regimes need to be progressive rather than regressive. According to Alba (2009), a progressive fiscal regime adjusts to changes in prices, volumes, and projects' operating conditions. Such flexibility is particularly important given the high volatility of oil, gas, and mineral prices. Progressive fiscal regimes linked to the projects' profitability assist in ensuring that the government and investors share benefits fairly.

The Natural Resource Governance Institute $(2015$, p. 2) consented that 'progressive fiscal tools give the government a larger share of the profit when profits increase while regressive fiscal tools give the government a lesser share as profits increase. Progressive fiscal tools, by contrast, protect the interests of companies during periods of low profitability while giving the government an ability to capture a significant share of windfalls when profits are high.' However, these progressive tools are frequently more difficult to enforce effectively, since auditing of operating costs and calculation of profits is needed. Limitation in adoption of progressive taxation is due to weaknesses in government capacity in many developing countries (Land, 2009). Based on United Nations Conference on Trade and Development [UNCTAD] (2007), such flaws are related to weaknesses in capacity to negotiate effectively with Transnational Corporations (TNCs), partly due to the lack of specialized skills needed to understand the fiscal options available or weaknesses in the tax administrations. 
Transparency and clarity - Clarity and simplicity are criteria described by Nakhle (2008) as being relevant to the administration and monitoring of the tax system, also referred to as administrative efficiency. Transparency principle relates to whether miners are fully informed about the tax liability that may flow from any proposed activity and the openness of the taxation arrangement and tax collection to examination by the community (Harman \& Guj, 2013). The case for transparency argues for liabilities to be predictable before any mining activity takes place (Nakhle, 2010) and Otto and Cordes (2002) affirmed that the standard of clarity recommends that tax system should encourage efficient and non-arbitrary administrative rules and regulations that are clearly understood by both taxpayers and government officials. Ambiguity in interpretation leads to increased perception of risk, opportunities for tax minimization strategies and conflict.

Risk sharing - The mix of taxes influences the distribution of risks between the state and mining companies. Otto et al. (2006, p. 10) reported that mining is a particularly risky activity. This is partly because of the long gestation period associated with the development of newest mines and the difficulty of anticipating prior to development all the potential technical, geological, economic, and political problems. In addition, most mineral commodity markets are highly volatile over the business cycle, with wide price fluctuations. A corporate profits tax and royalties based on profitability tend to distribute the risk of mining evenly between the state and companies.

Economic efficiency - An efficient tax as explained by Nakhle (2008) neither impedes nor reduces the productive capacity of an economy, nor does it create distortions in the allocation of resources by favoring one industry or type of investment at the expense of others. Based on Guj et al. (2013, p. 5) 'governments should formulate fiscal policy in a manner that ensures that the same level of exploration and production activities would occur whether or not the rent-collecting taxes were in place. The failure to achieve a reasonable level of economic efficiency will result in distortion of investment decisions and sub-optimal exploitation of the resources'. ICMM (2009) alike gave aspects of tax administration that companies consider to be important which include application of laws and agreements consistently, a fair court system that can resolve tax disputes and a system through which tax refunds are remitted to companies in a timely manner (delays can have a major impact on project cash flow).

Neutrality - Daniel et al. (2010, p. 190) reported that 'neutrality in taxation of mining and petroleum activities means that a tax does not, of itself, alter the order in which projects including exploration are undertaken; nor does it alter the speed of extraction, decisions about reinvestment, or the decision to abandon a petroleum field, or close a mine'. The objective of the concept of neutrality as perceived by Harman and Guj (2013) is that the taxation system should ensure that there is no impact on the exploration and production activities of mining. This condition of neutrality means that the system used to collect economic rent does not change the behavior or decisions of a mining company. Neutral fiscal tools give the state the same share of revenue whether profitability increases or decreases. Baunsgaard (2001) indicated that both progressive profit tax and corporate income tax (CIT) are neutral.

\subsection{Overview of the mineral taxation system in Zambia}

The mining taxation regime in Zambia has evolved in important ways since the government's privatisation of the mines. The authorities have changed elements of the regime in response to changing market conditions, evolving public policy needs, and as the authorities have developed experience with regulating private businesses after the years of state ownership (World Bank, 2015). Zambia has made changes to the fiscal regime since privatization of the mines as a means to optimize the country's benefits from the copper mining sector (Table 1). Zambia's mine tax regime is a variant of a traditional royalty-tax regime in which the government charges a royalty and then imposes the generally applicable tax regime, with perhaps special provisions for mining (Conrad, 2012). The country's mineral fiscal regime contained four key elements namely: mineral royalty; the generally applicable corporate tax (including some withholding taxes on remittances to non-residents); a variable profits tax; and equity participation. 
Chisakulo, E., \& Kambani, S.

Table 1

Evolving features of Zambia's fiscal regime since 1997

\begin{tabular}{|c|c|}
\hline Mining Fiscal Regime & Key Features \\
\hline $\begin{array}{l}\text { Development agreements } \\
\text { negotiated with individual } \\
\text { mines during privatisation } \\
\text { (1997 to March 2008) }\end{array}$ & $\begin{array}{l}\text { Agreements were made between the Zambian government and each company that bought } \\
\text { the assets of the former national company ZCCM. Each development agreement (DA) } \\
\text { contained a fiscal stability clause. }\end{array}$ \\
\hline $\begin{array}{l}\text { The "2008 regime" (April } \\
\text { 2008-March 2009) }\end{array}$ & $\begin{array}{l}\text { The } 2008 \text { reforms passed as part of the } 2008 \text { Mines and Minerals Act ruled that the } \\
\text { government should not enter into any special agreements for the development of } \\
\text { large-scale mining licenses; the reforms also annulled the development agreements. The } \\
\text { Act introduced a new tax regime with a higher tax burden: it set the company income tax } \\
\text { rate at } 30 \% \text {; it introduced a variable income tax and raised the mineral royalty rate to } 3 \% \\
\text { from } 0.6 \% \text {; and it set the withholding tax on services at } 15 \% \text { and introduced a windfall } \\
\text { tax. }\end{array}$ \\
\hline $\begin{array}{l}\text { The "2009 regime" (April } \\
\text { 2009-March 2012) }\end{array}$ & $\begin{array}{l}\text { This was in response to the mining companies' concerns about the revocation of the } \\
\text { development agreements, were the government reversed the lower capital depreciation } \\
\text { allowance and some other } 2008 \text { tax measures such as the windfall tax in its } 2009 \text { budget. }\end{array}$ \\
\hline $\begin{array}{l}\text { The "2014 regime" (April } \\
\text { 2012-December 2014) }\end{array}$ & $\begin{array}{l}\text { Further reforms were made to the mining tax regime in the } 2012 \text { budget. The two main } \\
\text { changes for the mining industry were the increase of the mineral royalty rates for copper } \\
\text { and cobalt to } 6 \% \text {, and separate treatment of hedging and operating income for income tax } \\
\text { purposes. }\end{array}$ \\
\hline $\begin{array}{l}\text { The "January } 2015 \text { regime" } \\
\text { (January 2015-June 2015) }\end{array}$ & $\begin{array}{l}\text { Corporate income and profits tax rates descended to zero. The government also set the } \\
\text { mineral royalty rate at } 20 \% \text { for output from open-pit mines and at } 8 \% \text { for output from } \\
\text { underground mines. }\end{array}$ \\
\hline $\begin{array}{l}\text { The "July } 2015 \text { regime" } \\
\text { (announced in April 2015) }\end{array}$ & $\begin{array}{l}\text { The government set the corporate income and profits tax rates at } 30 \% \text { and the mineral } \\
\text { royalty rate at } 9 \% \text { for output from all mines }\end{array}$ \\
\hline
\end{tabular}

Source. Zambia Extractive Industry Transparency Initiative (ZEITI), 2014; World Bank, 2015.

The performance of any fiscal regime in a country depends on the combination of all the tax instruments that it contains (Natural Resource Charter, 2014). The royalty-tax arrangement is widely used in many jurisdictions for mineral industry. The individual tax instruments pose a number of implementation challenges in the regulatory framework of the Zambia's mine fiscal regime.

Mineral royalty tax - In Zambia, mineral royalty tax is charged under the Mines and Mineral Development Act No 7 of 2008. Royalty means a payment received as consideration for the extraction of minerals. Mineral royalty taxes are levied as a fixed percentage of the value of a company's sales of a particular mineral. The mineral royalty rate effective July, 2015 based on the 2015 fiscal regime was $9 \%$ on all outputs for both underground and open cast operations which was later changed to a sliding rate of 4-6\% during the June 2016 fiscal regime. Ad valorem royalty rates for copper vary, generally ranging between 0 and $8 \%$ (Conrad, 2012). Zambia's mineral royalty rate in the January 2015 fiscal regime of $8 \%$ for underground mines and $20 \%$ for open cast mines were above international norms. However, as indicated by Conrad (2012), the rates may be misleading because the base to which the royalty rate is applied also varies across countries.

Corporate income tax - All extractive companies are taxed on their taxable income, which is determined in line with the Zambian Income Tax Act. Income covers revenue less all tax allowable expenditure. This tax is applied as a fixed percentage of a company's profits during a particular period, usually one year. The company tax rates are $30 \%$ for mining incomes and $35 \%$ for hedging incomes (Zambia Extractive Industry Transparency Initiative, 2015). The $30 \%$ CIT rate is similar to the rates in most other mining countries, where typically the rate is between 20-30 \% (Conrad 2012). Despite its widespread use, CIT can be a complex tax. Manley (2013) consented that this is because the taxable profits which is the base on which the tax rate is applied can be defined in numerous ways with many additional provisions that can be used to alter the amount of tax that is payable.

Variable profits tax - Variable profit tax is a tax on company profits charged under the Income Tax Act. The company tax rate is $30 \%$. Variable profit tax rate applied to profits that go above $8 \%$ of the gross sales. Zambia Revenue Authority (ZRA) had a formula to calculate the variable profit above the threshold. Variable profit tax can go up to a maximum of $45 \%$ (Zambia Extractive Industry Transparency Initiative, 2014). 
State equity participation - State or government equity participation is the share of the state in the distributed profits of a company. Conrad (2012) discussed that some countries, including Zambia, have chosen to take equity positions in particular mining enterprises. Potential financial gains include dividends from shares and capital gains. Lundstøl, Raballand, and Nyirongo (2013) noted that the government in Zambia still has in their regulation and legislation the ambition to participate with minority free or carried ownership interests in the mining sector. The government retains a share of between 5-20\% carried ownership interests in several of the privatised mines, managed through the state-dominated holding company, Zambia Consolidated Copper MinesInvestments Holdings (ZCCM-IH). Equity participation varies by mine and there appears to be a form of price participation. Conrad (2012) reported that ZCCM-IH has some price participation agreements with firms in which it holds equity. However, as indicated by Manley (2012) and Conrad (2012), these details of participation agreements and contractual relationship between the ZCCM-IH and the companies in which it holds equity are generally none available.

Withholding taxes (WHT) - Withholding taxes are imposed on payments to non-residents sourced in the country imposing the tax (Conrad, 2012). This is a tax where any person or company making certain payments is required to deduct from such payments and remit to ZRA. The payments that attract WHT include management and consultant fees, commissions, rent dividends and payments to non-resident contractors. The WHT rate in Zambia is $15 \%$ (Zambia Extractive Industries Transparency Initiative, 2014). The applicable WHT for dividends for companies carrying on mining operations in Zambia is 0\% (Zambia Development Agency [ZDA], 2011).

\section{Materials and method}

\subsection{Data collection}

This study employed both questionnaires and semi-structured interviews for data collection. Mine taxation is considered an emotive topic in Zambia and in this situation, questionnaires were adopted in support of indication by Kumar (2011) that if the study is about issues that respondents may feel reluctant to discuss with an investigator, a questionnaire may be the better choice as it ensures anonymity. A closed-ended questionnaire was used to establish demographic attributes of the respondents and assess their perceptions on the attributes of 'good tax' criteria using a Likert scale format. The attributes used in the study statements included stability, progressivity, neutrality, risk sharing, equity, transparency and certainty, regressiveness, and economic efficiency. Correspondingly, semi-structured interviews were conducted to get in depth information from respondents.

\subsection{Sampling}

For both sampling tools, a non-probability purposive sampling approach was used. This type of method is used: where the total population may not be well defined for study in certain cases; and if there is no desire or need to generalize to a population parameter (Cooper \& Schnidler, 2014). A total of 122 questionnaires were distributed to various groups in the mining industry to solicit for their perceptions on the taxation system based on the principles of 'good tax' criteria. Adams, Khan, Raeside, and White (2007) argued that success with surveys often depends on good response rates, which is the number of respondents divided by the number approached. For this survey, a response rate of $68 \%$ was achieved since 82 questionnaires were responded to from the 122 distributed. Similarly, 13 interviewees from the different stakeholder groups participated and gave their perceptions on various closed-ended and open-ended questions covering demographics and principles of taxation for the Zambian mine fiscal system.

\subsection{Data measurement}

The study used a five-point Likert scale questionnaire with a value of 1 indicating that the respondent strongly agrees with the item while the highest number 5 indicates that the respondent strongly disagrees with 
Chisakulo, E., \& Kambani, S.

that item in the construct [i.e. 1=Strongly Agree (SA), 2=Agree (A), 3=Neutral (N), 4=Disagree (D), and $5=$ Strongly Disagree (SD)]. The participants were asked to agree or disagree with each of the eight Likert item statements forming a construct on 'good tax' criteria. Each response was given a numerical score to reflect its degree of attitudinal favorableness, and the scores summed to measure the participant's overall attitude (Cooper \& Schindler, 2014).

\subsection{Data analysis}

As a means to evaluate and interpret data in order to make conclusions, IBM, SPSS Statistics 20 and Microsoft Excel were employed. Descriptive statistics used are recommended for ordinal measurement scale items that include a mode or median for central tendency and frequencies for variability (Bhattacherjee, 2012; Boone, Jr., \& Boone, 2012). Cross tabulations from questionnaires were used in order to determine if there were significant variations in respondents' perceptions on the evaluated items in the construct.

\subsection{Realization of reliability and validity}

Reliability estimates the consistency of the measurement and is usually assessed in two ways namely by checking the stability of measurement using the test-retest method (repeatability) and by examining internal consistency (Adams et al., 2007). For this study, no re-test method was used because of time constraint while for internal response consistency, Brown (2011) stated that the reliability of Likert scales should be checked using Cronbach's alpha which according to Zikmund, Babin, Carr, and Griffin (2009) should be at least 0.6 for a scale to be considered as acceptably reliable. The reliability statistics using IBM, SPSS Statistics 20 for the 8-item rating statements assessed on 'good tax' criteria from the questionnaire gave a reliability coefficient (Cronbach's alpha) determined at 670 .

Saunders, Lewis, and Thornhill (2009) identified threats to reliability dealing with error and bias for both subjects (participants) and observers. For this study, to avoid participant error, the subjects were allowed a reasonable time allocated of three to four weeks to complete the questionnaires. In order to reduce on participant bias in terms of giving desirable responses in situations where subjects were identified individually by the researchers, every effort was made to distribute the questionnaires through responsible officers in organizations to uphold the anonymity of the respondents. As a way to reduce on observer error that can occur depending on the manner in which questions are asked from the tools of data capturing, the study employed questionnaires which were structured and standardized making the questions to be interpreted by respondents in a consistent and similar manner. Similarly, observer bias that could arise in situations where the observer seeks to gather information that aspires to satisfy the researcher's standpoint was controlled by ensuring that the researchers remained neutral and not emotional in the way data was gathered and analyzed.

Validity (construct validity) is the extent to which a measure adequately represents the underlying construct that it is supposed to measure (Bhattacherjee, 2012). Error from researchers and the subjects participating in the project can affect the validity (Brink, 1993). To reduce on researcher error, the observers remained objective and impartial by not taking sides with respondents from the various groups under study in the population. The threat from subjects participating in the research as well was reduced by standardizing the structure of questions in the questionnaire and semi-structured interview to give respondents an opportunity to interpret the questions in a similar way.

Triangulation is a validity procedure where researchers search for convergence among multiple and different sources of information to form themes or categories in a study (Creswell \& Miller 2000). Methodological triangulations were used that involved the use of multiple qualitative and/or quantitative methods to study the program (Guion, David, Diehl, \& McDonald, 2011). Methodological triangulation employed structured interviews and questionnaires and the findings from both methods gave some similarity, indicating validity in the findings. 


\subsection{Limitation of study}

This study developed only descriptive research statements (Mackey \& Gass, 2005) for which answers were being sought. Descriptive research questions as noted by Leech, Barrett and Morgan (2005) are not answered with inferential statistics and merely describe or summarise data, without trying to generalise to a larger population of individuals. Descriptive analysis just involves understanding data through graphic displays, through tables, and through summary statistics (Bernard, 2006).

The other study limitation was the non-use of parametric inferential statistics because non-random sampling was applied, the types of research statements designed were not expressed as exploration of relationship between variables and no research hypotheses were developed which are predictive statements about the relationship between variables. Furthermore, the study was concerned with issues dealing with mine taxation which remain a source of contentious discussions in Zambia. Based on this, most of the respondents felt uncomfortable discussing such matters openly for fear of getting quoted and losing their jobs. This had an influence on creating responses that do not reflect the actual views or behaviours for respondents.

This study was conducted in Zambia thereby making generalisation of results only to the Zambian situation. Based on this, the international collectiveness of the findings emanating from this study might not be ascertained without similar studies being replicated in other jurisdictions. Lastly, this study did not pick on any specific taxation regime for evaluation but gave an overall perception of the mine fiscal regimes from 1997 Privatization and Development Agreement regime to post-July 2015 fiscal regime.

\section{Results and discussions}

Fiscal tools (taxation instruments) represent the government's vehicles for collecting revenues from extractive industry projects. This study examined the performance of the Zambian taxation regimes in relation to attributes of 'good tax' criteria using the key fiscal tools (corporate income tax, royalties, variable profits tax, and equity stake).

\subsection{Interview analysis}

Analysis of general respondents' information showed that the majority of interviewees had more than 10 years of experience (Figure 1) giving adequate experience in their profession to comprehend taxation matters in the Zambian mining industry.

Figure 1. Number of interviewees based

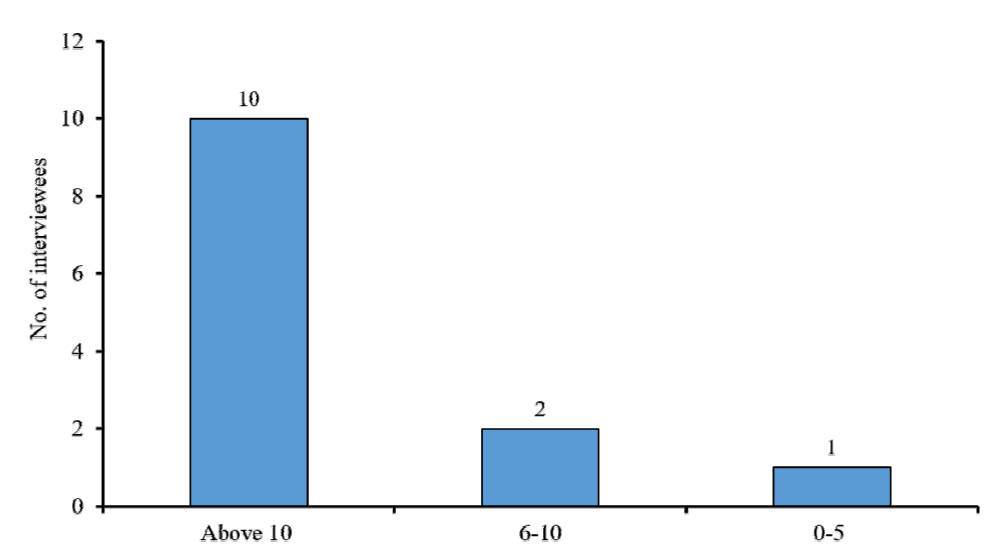

on years of experience

The interviewees were drawn from various stakeholder groups comprising the mining industry (Figure 2). The copper mining companies constituted the key stakeholder group involved in the operations of the extractive industry projects. Zambia Revenue Authority (ZRA) is concerned with tax administration functions while the Ministry of Mines is the mining authority monitoring the industry. Government agencies-Zambia Development Agency (ZDA) and Zambia Extractive Industries Transparency Initiative (ZEITI) are respectively concerned with investment promotion and transparency in revenue reporting in the mining industry. Zambia Institute for 
Chisakulo, E., \& Kambani, S.

Policy Analysis and Research (ZIPAR) and Action Aid represented the Civil Society Organizations (CSOs) who provide research and advocacy on various issues affecting the mining industry.

Figure 2. Number of interviewees based on represented organizations

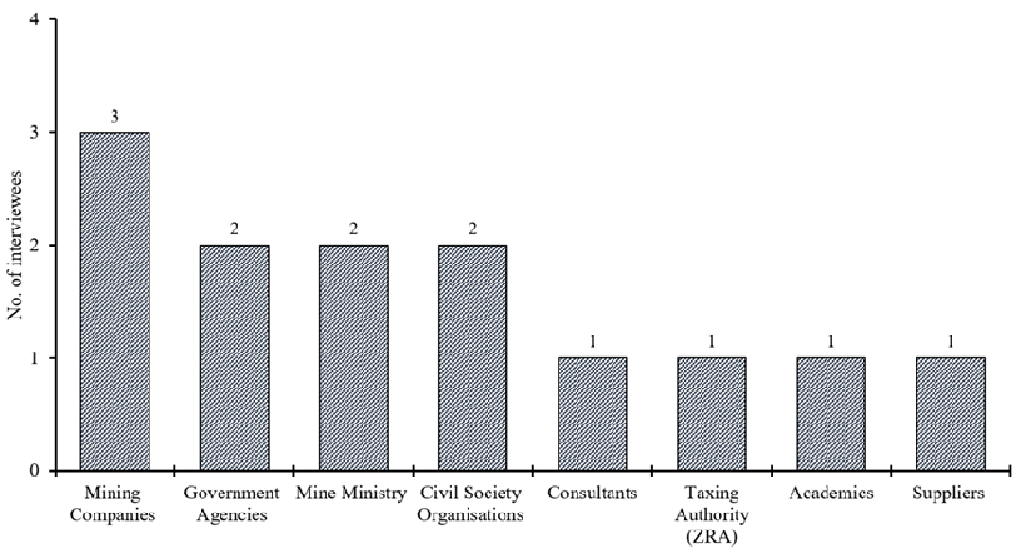

Most of the interviewees were of the opinion that the Zambian mine tax regimes fail to respond to the principles of 'good tax' criteria which formed the Likert items dealing with: robustness (flexibility); stability; neutrality; transparency; and risk sharing (Figure 3). However, on the progressivity of the taxation systems, interviewees were indifferent.

Figure 3. Responsiveness of the tax system to 'good tax' criteria

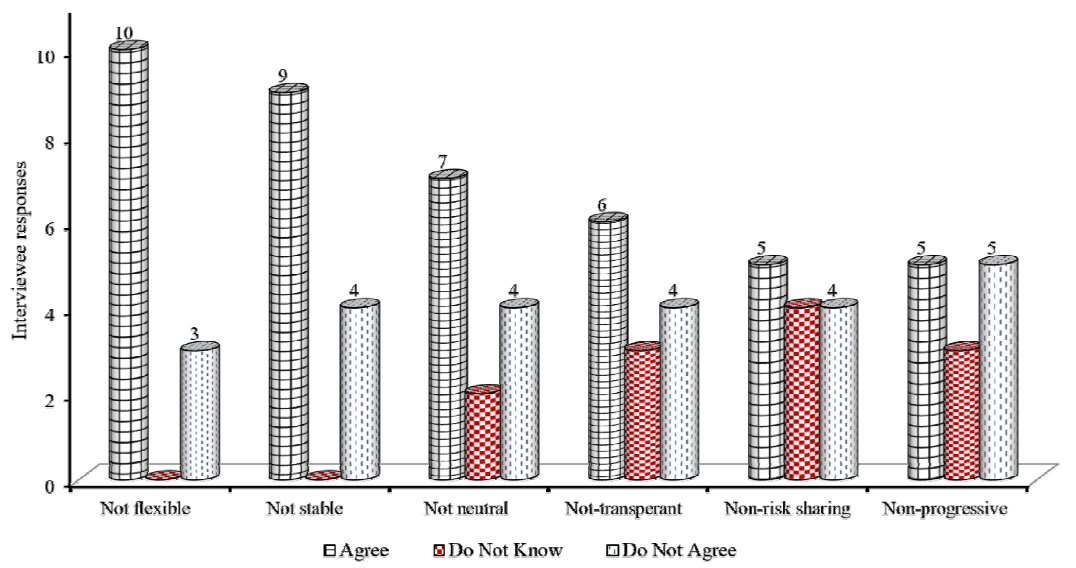

The interviewees provided perceptions on the failures of the Zambian mineral taxation systems to respond to the attributes of 'good tax' principles. Most of them felt that:

$>\quad$ the government's policy formulations are inconsistent and responsible for instabilities in the mine fiscal regimes;

$>\quad$ there is a general lack of stabilization arrangements in the mine fiscal regimes;

$>$ government places more emphasis on regressive revenue based fiscal tools (royalties) due to failures to comprehend the parameters of the mineral projects like unit operating costs;

$>\quad$ the gross mineral royalty rates applied are above the international norms;

$>\quad$ there is mistrust and poor consultation on matters of revenue appropriation between the government and the investors;

$>\quad$ weak institutional capacities exist affecting enhanced tax administration, mine auditing and regulation; and

$>\quad$ the taxation systems are not efficient and still fail to resolve the tax refund (VAT) concerns.

\subsection{Questionnaire analysis}

The frequencies and percentages of demographic traits of respondents based on three attributes dealing with place of work, years of experience and type of occupation were as presented in Table 2. A combined experience of more than six years for the respondents gave $92 \%$. This signifies realistic years of experience for experts to comprehend taxation matters. Various professions were also involved in different occupations in the mining industry at the time of study. 
Table 2

Demographic characteristics of respondents

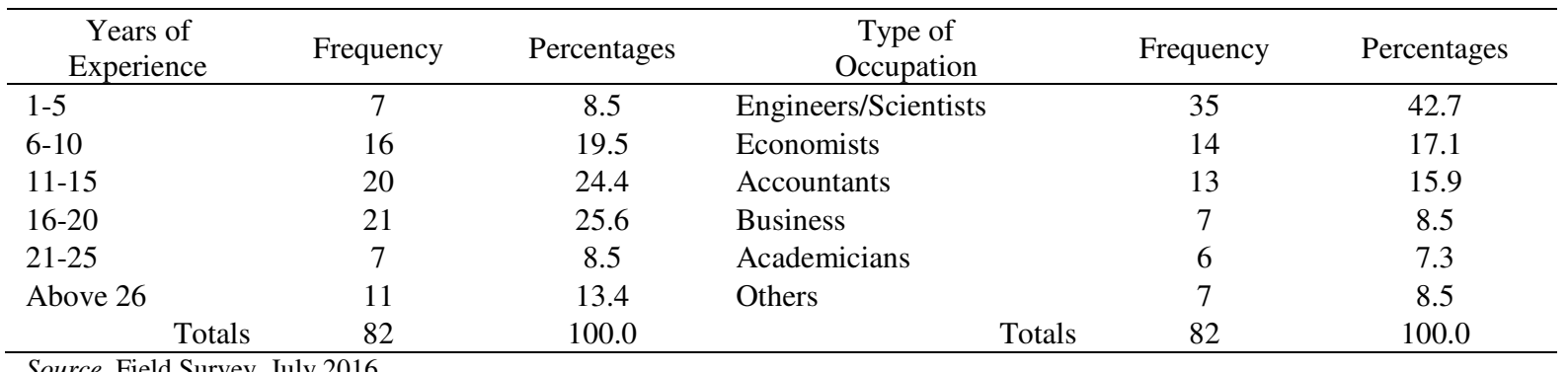

Source. Field Survey, July 2016.

Different respondents worked for diverse stakeholder groups in the mining industry. The mining companies at the time of the study constituted the largest stakeholder group with $32 \%$ of the respondents (Figure 4).

Figure 4. Organisations which

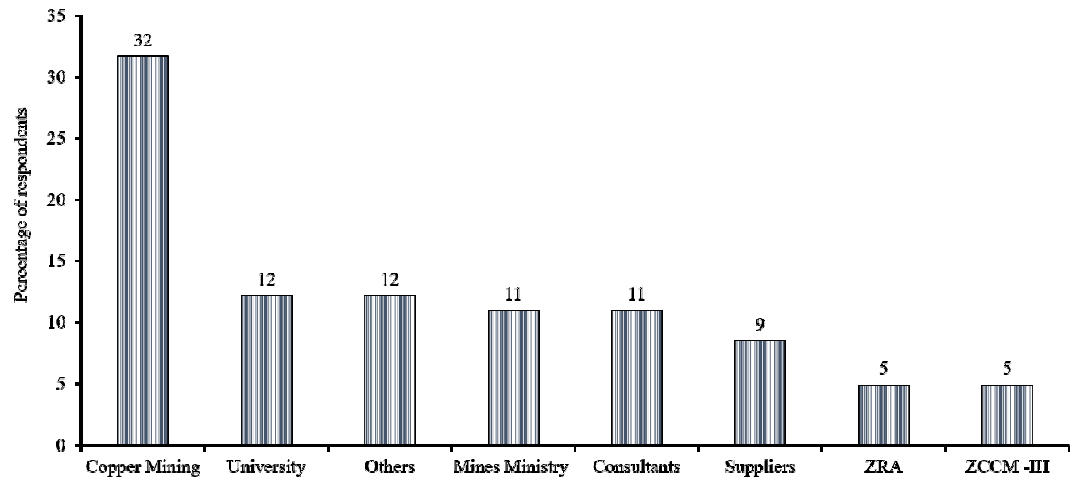

respondents belonged to

The frequency distribution of the experts' opinions from 82 responses on the eight attributes of a 'good tax' criteria dealing with; stability, progressivity, neutrality, risk sharing, equity, transparency and clarity, regressiveness, and efficiency are as presented in Table 3.

Table 3

Respondents' perceptions on the tax attributes for the fiscal regimes

\begin{tabular}{|c|c|c|c|c|c|c|c|c|c|}
\hline No & Study statement & Mode & Median & $* *$ SA & $\mathrm{A}$ & $\mathrm{N}$ & $\mathrm{D}$ & SD & TR \\
\hline 1 & The tax regimes are stable & 4 & 4 & $\begin{array}{c}2 \\
(2.4)\end{array}$ & $\begin{array}{c}10 \\
(12.2)\end{array}$ & $\begin{array}{c}4 \\
(5.0)\end{array}$ & $\begin{array}{c}43 \\
(52.4)\end{array}$ & $\begin{array}{c}23 \\
(28.0)\end{array}$ & $\begin{array}{c}82 \\
(100)\end{array}$ \\
\hline 2 & Tax systems are progressive & 4 & 4 & $\begin{array}{c}1 \\
(1.2)\end{array}$ & $\begin{array}{c}12 \\
(14.6)\end{array}$ & $\begin{array}{c}10 \\
(12.2)\end{array}$ & $\begin{array}{c}32 \\
(39.0)\end{array}$ & $\begin{array}{c}27 \\
(32.9)\end{array}$ & $\begin{array}{c}82 \\
(100)\end{array}$ \\
\hline 3 & Taxation systems are neutral & 4 & 3 & $\begin{array}{c}5 \\
(6.1)\end{array}$ & $\begin{array}{c}26 \\
(31.7)\end{array}$ & $\begin{array}{c}13 \\
(15.9)\end{array}$ & $\begin{array}{c}33 \\
(40.2)\end{array}$ & $\begin{array}{c}5 \\
(6.1)\end{array}$ & $\begin{array}{c}82 \\
(100)\end{array}$ \\
\hline 4 & Tax systems allow risk sharing & 4 & 4 & $\begin{array}{c}2 \\
(2.4)\end{array}$ & $\begin{array}{c}8 \\
(9.8)\end{array}$ & $\begin{array}{c}18 \\
(22.0)\end{array}$ & $\begin{array}{c}31 \\
(37.8)\end{array}$ & $\begin{array}{c}23 \\
(28.0)\end{array}$ & $\begin{array}{c}82 \\
(100)\end{array}$ \\
\hline 5 & Taxation systems are equitable & 4 & 4 & $\begin{array}{c}1 \\
(1.2)\end{array}$ & $\begin{array}{c}10 \\
(12.2)\end{array}$ & $\begin{array}{c}9 \\
(11.0)\end{array}$ & $\begin{array}{c}37 \\
(45.1)\end{array}$ & $\begin{array}{c}25 \\
(30.5\end{array}$ & $\begin{array}{c}82 \\
(100)\end{array}$ \\
\hline 6 & $\begin{array}{l}\text { Tax regimes are transparent and } \\
\text { certain }\end{array}$ & 5 & 4 & $\begin{array}{c}3 \\
(3.7)\end{array}$ & $\begin{array}{c}14 \\
(17.1)\end{array}$ & $\begin{array}{c}7 \\
(8.5)\end{array}$ & $\begin{array}{c}22 \\
(26.8)\end{array}$ & $\begin{array}{c}36 \\
(43.9)\end{array}$ & $\begin{array}{c}82 \\
(100)\end{array}$ \\
\hline 7 & Tax regimes are regressive & 2 & 3 & $\begin{array}{c}13 \\
(15.9)\end{array}$ & $\begin{array}{c}22 \\
(26.8)\end{array}$ & $\begin{array}{c}17 \\
(20.7)\end{array}$ & $\begin{array}{c}16 \\
(19.5)\end{array}$ & $\begin{array}{c}14 \\
(17.1)\end{array}$ & $\begin{array}{c}82 \\
(100)\end{array}$ \\
\hline 8 & $\begin{array}{l}\text { Taxation systems are economically } \\
\text { efficient }\end{array}$ & 4 & 4 & $\begin{array}{c}1 \\
(1.2) \\
28 \\
4 \% \\
\end{array}$ & $\begin{array}{c}20 \\
(24.4) \\
122 \\
19 \% \\
\end{array}$ & $\begin{array}{c}12 \\
(14.6) \\
90 \\
14 \% \\
\end{array}$ & $\begin{array}{c}35 \\
(42.7) \\
249 \\
38 \% \\
\end{array}$ & $\begin{array}{c}14 \\
(17.1) \\
167 \\
25 \% \\
\end{array}$ & $\begin{array}{c}82 \\
(100) \\
656 \\
100 \% \\
\end{array}$ \\
\hline
\end{tabular}

Note. ${ }^{* * \mathbf{S A}}=$ Strongly Agree, $\mathbf{A}=$ Agree, $\mathbf{N}=$ Neutral, $\mathbf{D}=$ Disagree, $\mathbf{S D}=$ Strongly Disagree, $\mathbf{T R}=$ Total Responses.

(All the figures in brackets are percentages).

Source. Field Survey, July 2016.

Cross tabulation results - Cross tabulation results showed no major variations of respondents' perceptions from different stakeholder groups forming the mining industry. This demonstrates that most of the 'experts' from the various organizations $(63 \%)$ had a combined score of 'strongly disagree' and 'disagree' that the Zambian 
Chisakulo, E., \& Kambani, S.

mine tax regimes respond affirmatively to the studied eight attributes of the 'good tax' criteria (Table 4).

Table 4

Cross tabulation of experts' responses from different organizations

\begin{tabular}{lcccc}
\hline \multirow{2}{*}{ Organization } & \multicolumn{4}{c}{ Responsiveness of the tax systems to 'good tax' criteria } \\
\cline { 2 - 5 } & $* *$ SA + A & $\mathrm{N}$ & $\mathrm{SD}+\mathrm{D}$ & Total \\
\hline ZRA & $14(43.75 \%)$ & $5(15.63 \%)$ & $13(40.63 \%)$ & $32(100 \%)$ \\
Mines Ministry & $20(27.78 \%)$ & $10(13.89 \%)$ & $42(58.33 \%)$ & $72(100 \%)$ \\
Copper Mining & $45(21.63 \%)$ & $26(12.50 \%)$ & $137(65.87 \%)$ & $208(100 \%)$ \\
ZIPAR & $6(37.50 \%)$ & $4(25.00 \%)$ & $6(37.50 \%)$ & $16(100 \%)$ \\
University & $13(16.25 \%)$ & $14(17.50 \%)$ & $53(66.25 \%)$ & $80(100 \%)$ \\
Consultant & $11(15.28 \%)$ & $9(12.50 \%)$ & $52(72.22 \%)$ & $72(100 \%)$ \\
Suppliers & $15(26.79 \%)$ & $4(7.14 \%)$ & $37(66.07 \%)$ & $56(100 \%)$ \\
ZCCM -IH & $8(25.00 \%)$ & $5(15.63 \%)$ & $19(59.38 \%)$ & $32(100 \%)$ \\
Others & $18(20.45 \%)$ & $13(14.77 \%)$ & $57(64.77 \%)$ & $88(100 \%)$ \\
& $150(23 \%)$ & $90(14 \%)$ & $416(63 \%)$ & $656(100 \%)$ \\
\hline
\end{tabular}

Note. ${ }^{* *} \mathbf{S A}+\mathbf{A}=$ Strongly Agree +Agree, $\mathbf{N}=$ Neutral, SD + D = Strongly Disagree + Disagree.

Source. Field Survey, July 2016.

The copper mining companies being a larger sector of the mining industry constituted $32 \%$ of the overall respondents. Their entire response gave a percent score for 'disagree' and 'strongly disagree' at $66 \%$ for the tax regimes' response to 'good tax' criteria items. This result matched well with the overall perceptions (at 63\%) noted by the respondents from the other groups in the entire mining industry.

\subsection{Discussions}

The results on the responsiveness of the tax systems to the attributes of the 'good tax' criteria are as presented in Figure 5. This section provides discussions on the eight used Likert items (statements) forming the 'good tax' criteria.

Stability - Only $15 \%$ of the respondents had a combined score of 'agree' and 'strongly agree' to the statement that the current Zambian taxation regimes are stable, while $80 \%$ of the respondents had a combined score of 'strongly disagree' and 'disagree' with 5\% remaining neutral (Table 3, Figure 5). The prevalent dissent response is consistent with Manley (2013) who pointed out that the Zambian tax regime provides no contracted or legislated stability clauses, unlike the Development Agreement (DA) regime. The DA regime existed during the privatisation period of the Zambian copper mining industry where stabilization clauses formed part of the mine agreements. World Bank (2015) reported that mining taxation regime in Zambia has evolved in important ways since the government's privatisation of the mines. These changes to the fiscal regimes since privatization were meant to optimize the country's benefits from the copper mining sector.

To date, Zambia, however, still faces mine taxation challenges because of lack of fiscal stability resulting in regular reviews and amendments made to the mine fiscal terms of the country's mineral resources concession. These regular changes made to the fiscal regimes are premised on the need to balance the requirements of attracting investment and maximizing national benefits from the country's mineral resources before they get exhausted.

Figure 5. Responsiveness of the taxation systems to 'good tax' criteria

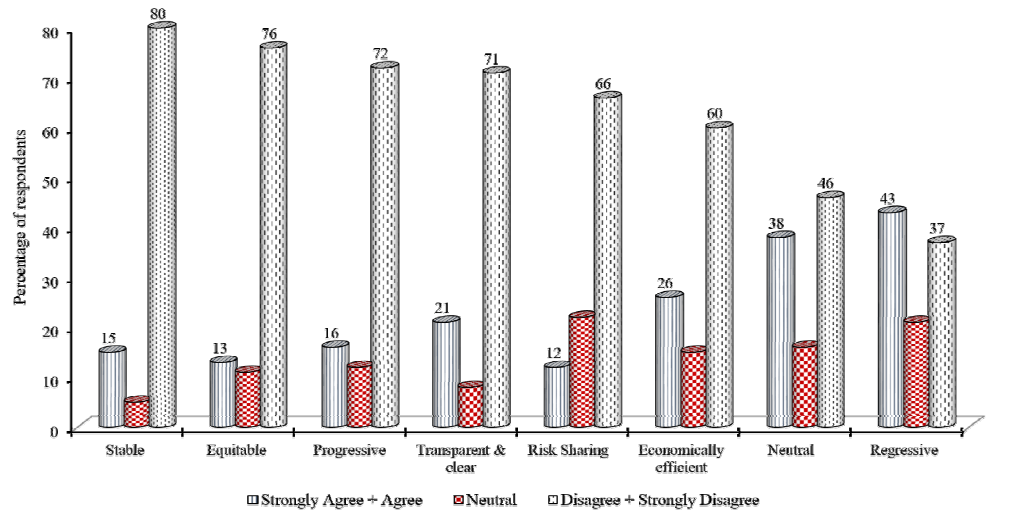


Equity - 76\% of the respondents indicated that the tax regimes in Zambia are not equitable while only 13\% were supportive of the equitable nature of the fiscal regimes. During the January 2015 mine taxation regime, Zambia introduced a mineral royalty tax (MRT) system with differentiated royalty rates for underground mines (8\%) and open cast mines (20\%) without corporate income tax. The changes were necessitated after government perceived that different cost structures existed for underground mining and open cast mining influencing the amounts of revenues generated. Such measures to implement such a differentiated tax regime are synonymous with vertical equity argued by Nakhle (2008) that projects are required to pay tax based on their ability to pay. However, these changes made to the 2015 Zambia's mine fiscal regime where met with strong opposition from the mining sector as they coincided with low copper prices and cash flow problems exasperated by strict enforcement of Value Added Tax (VAT) Rule 18 (PriceWaterhouseCoopers, 2015).

Information asymmetry with respect to mining cost profiles still exists in the Zambian mining industry. Harman and Guj (2013) recounted that violation on vertical equity principle exists when a tax system fails to discriminate between high rent and low rent operations. In terms of taxing mines based on their ability to pay more, Manley (2013) revealed that Variable Profits Tax (VPT) is attractive in that it is widely perceived by the public as being "fair". This is a tax which is the company equivalent of the progressive personal income tax found in most countries, where the rich pay a higher proportion of their income in tax than the poor. This can justify the increased taxation for companies earning exceptionally high profits.

These equity concerns on taxation are applicable to Zambia because existing information asymmetry puts the government in a weaker position to argue taxation matters from an equitable and informed basis. The Zambian tax regimes fail to respond to the principle of equity because of failures to introduce a taxation system that adequately comprehends differences in the profitability of the mining operations.

Progressivity - Only 16\% of the respondents agreed to the statement that the mine fiscal regimes in Zambia are progressive while $72 \%$ of the respondents disagreed. In 2008, Zambia imposed two progressive taxes namely-Windfall Profits Tax (WPT) and VPT to capture excess profits. Their aim was to be progressive - as some measure of a company's profitability increases, so does the tax burden (Manley, 2013). However, designing such a tax requires mechanisms that can capture windfall profits but without overly reducing the expected returns for the investors (Manley, 2012). The windfall tax employed sales revenue as a tax base for the company. This tax, however, was removed in 2009 since it never allowed for deduction against taxable profits for the calculation of company income tax (CIT).

Equally, Zambia faced implementation challenges to capture revenues from the progressive VPT because it allowed deductions to taxable profits just like CIT. This VPT was applied up to $15 \%$ when the taxable income exceeds $8 \%$ of gross sales. The deductions allowed in the VPT included (Manley, 2012) the depreciation allowances and loss carry forward provisions. Since mining operations typically incur large costs up-front, these deductions can ensure that taxable profits are zero for many years. Since the VPT applied the same taxable profits as the CIT that included costs within its tax base, it made the fiscal tool harder to administer. Consequently, the Zambian government discharged this tax in post 2015 fiscal regime.

Transparency and certainty - $71 \%$ of the respondents indicated that the Zambian tax regimes are not transparent and certain while only $21 \%$ consented to the regimes being transparent. Collier (2010) clearly specified that resource taxation has some problems associated with information asymmetry. There are concerns that during formulation of the tax regime, there is little interaction with the mining industry and the government thereby creating some secrecy. Some of these confidentialities can prevent government institutions to effectively regulate the mining industry and undertake tax administration duties.

In Zambia, lack of transparency in the fiscal regime existed from the period of the Development Agreements (Dymond, Lambrechts, \& Chase, 2007; Lungu, 2009; Simpasa, Hailu, Levine, \& Tibana, 2013). This is a time when agreements allowed several preferential treatments with respect to tax sometimes made on project basis. Manley (2012) observed that the details of the Development Agreements were different for each company and 
were confidential. Even access within government and by the tax authority appeared to have been extremely limited. Das and Ross (2014) discussed such transparency challenges indicating that a mining project - Konkola Copper Mines (KCM) has concessions legalised in Vedanta's secret Development Agreements. These were negotiated by Clifford Chance with the Zambian government which is fixed until 2018. The deal guarantees the project a royalty rate of only $0.6 \%$ and allows it to deduct $100 \%$ of capital allowance from its investments. The Lusaka Times (2015) similarly reaffirmed the lack of transparency on revenues and profits from the mining companies and a lack of consistent and effective mining taxation policy from the government.

Risk sharing - Only $12 \%$ of the respondents agreed to equitable risk sharing between the government and investors under the Zambian mine fiscal regimes while $66 \%$ of the respondents disagreed leaving $22 \%$ with a neutral perception. Baunsgaard (2001) observed that a fiscal regime will meet impacts on the risk sharing between the government and the investors. A tax will reduce investor risk if it shifts some commercial (project) risk to the government. Clausing and Durst (2015) equally noted that given the role of risk, uncertainty, and economic rents, a tax on profits or resource rents may be particularly appealing. From the total fiscal instruments used in the Zambian mine fiscal regimes, mineral royalty tax linked to revenue (sales) as a tax base is considered a non-risk sharing tax tool as taxes are paid even when profitability is not registered. While CIT in Zambia is applied as a tax instrument meant to share risk by nature, the challenge is that it is a profit-based tax designed to allow for loss carry forwards and huge capital deductions claimed for cost recoveries. This could result in diminutive taxable incomes and zero profits in some cases.

Economic efficiency - $60 \%$ of respondents indicated that the mine tax regimes in Zambia are not economically efficient while only $26 \%$ agreed to the regimes being efficient. Manley (2013) stated that a taxation system should be administratively feasible because if it is too complex for the tax authority to administer, mining companies can avoid paying it. Otto et al. (2006) described a tax on corporate income or profits to be more efficient, since such a tax does not alter the optimal output of companies striving to maximize profits, and marginal ore will remain profitable to exploit. A designed fiscal regime should be economically efficient with minimal costs of administering and enforcing a tax. In Zambia, there is still a standoff between the government and mining companies over the withheld Value Added Tax (VAT) refunds. The amounts for VAT refunds claimed by mining companies are higher than what the country gets in taxes from some mining projects.

Neutrality - 46\% of respondents indicated that the mine tax systems in Zambia are not neutral while 38\% agreed that the tax systems exhibit some traits of neutrality. Despite most of the respondents claiming non-neutrality of the regime, a median score of 3.00 showed that respondents were also undecided about this attribute. Usually, taxes applied on profits like corporate income tax (CIT) are considered neutral to progressive. However, profit taxes are more preferred by investors than resource owners (i.e. governments) since they are allowed for deductions and loss carry forward provisions which reduce the taxable incomes. CIT as a taxation tool has not been considered neutral by the government in Zambia. During justification for the 2015 mine fiscal regime change, the Zambian Finance Minister revealed that the tax structure was simply illusory as only two mining companies were paying CIT under the previous regime as most of them claimed that they were not in the tax paying position (Times of Zambia, 2015). However, the higher royalty rates (imposed in the Zambian mine tax regime for January 2015) were distortionary (non-neutral) and discouraged investment and production in the sector.

Regressive tax - 43\% of the respondents concurred that Zambia's tax regimes are regressive while $36 \%$ felt differently. A median score of neutral (3.00) indicated that respondents were undecided on this attribute. Regressive tax occurs when the tax burden decreases failing to capture proportionally higher rents on projects that are more profitable. Royalties imposed on production and not profits constitute a regressive form of taxation (Land, 2009). High taxes applied on revenues (royalties) and front-loaded taxes are regressive. In Zambia, changes were made to the mineral royalty rates from $6 \%$ in 2012, to $20 \%$ for output from open-pit mines and $8 \%$ for output from underground mines during the January 2015 fiscal regime. In July 2015, the regime put the mineral royalty tax at $9 \%$. These changes made to the royalty rates in the fiscal regime had a strong tendency to 
be regressive in the eyes of the investors.

Based on studies conducted by Gajigo, Mutambatsere and Ndiaye (2012), the average royalty rate forming operations in the sample of 23 African countries was found to be approximately $3.5 \%$ while the modal rate was $3 \%$. However, Zambia's mineral royalty rates indexed to copper prices (sliding at 4-6\% of gross revenue for the June 2016 fiscal regime) were considered slightly above the gross average noted by Gajigo et al. (2012) at 3.5\%. Furthermore, Chisakulo and Kambani (2017) observed that the tax system in Zambia for the post June 2016 was regressive with royalty sensitivity. The upper threshold rate of $6 \%$ in the sliding royalty system will still make the taxation system regressive with copper price streams higher than $\$ 6,000 /$ tonne. Based on the preceding discussions, Zambia needs to make its fiscal regimes responsive to the attributes of 'good tax' criteria. Some of the measures to assume towards achieving a responsive and robust tax system for the country are summarized in Table 5 .

\section{Table 5}

Measures to embrace for the Zambian tax systems to respond to attributes of 'good tax' criteria

\begin{tabular}{|c|c|}
\hline Attribute & Measures for Zambia \\
\hline Stability & $\begin{array}{l}\text { Introducing well-structured fiscal stability agreements (FSAs) is needed. } \\
\text { Zambia should properly manage the sliding scale fiscal tools to ensure stability. }\end{array}$ \\
\hline Neutrality & $\begin{array}{l}\text { Government to improve on the challenges of information asymmetry so that technical } \\
\text { attributes for mineral projects (which are mostly secrets of the mining companies) are } \\
\text { fully comprehended. }\end{array}$ \\
\hline Progressiveness & $\begin{array}{l}\text { Policymakers need to introduce well-designed excess profit taxes that raise taxes in } \\
\text { proportion to increasing pre-tax profitability on a progressive basis. } \\
\text { The government needs to evaluate the practicalities of introducing economic rent } \\
\text { taxes. } \\
\text { Government to reinforce operations of the sliding fiscal tools indexed to movements } \\
\text { in commodity prices. }\end{array}$ \\
\hline Transparency and clarity & $\begin{array}{l}\text { Zambia should initiate wide multi-stakeholder consultations during fiscal regime } \\
\text { formulation and prior to implementation of the taxation regimes to ensure } \\
\text { predictability. } \\
\text { Government to improve on contests touching on information asymmetry. }\end{array}$ \\
\hline Risk Sharing & $\begin{array}{l}\text { State to strengthen institutional capacities required to administer efficiently the } \\
\text { risk-sharing profit-based taxes. } \\
\text { Policymakers to introduce well-designed progressive profit taxes. }\end{array}$ \\
\hline Equity & $\begin{array}{l}\text { The state needs to develop capacities to capture full information about mine projects } \\
\text { based on identified poly-metallic deposits, known variations in technical and deposit } \\
\text { parameters, and differential costs of operations and revenue raising potential in order } \\
\text { to apply vertical equity systems (ability to pay taxes). }\end{array}$ \\
\hline Economic Efficiency & $\begin{array}{l}\text { Government to make certain that taxing authority applies laws and agreements in an } \\
\text { efficient and consistent manner by ensuring that tax refunds to companies are done } \\
\text { without delay. } \\
\text { The state to improve institutional capacities to administer income-based taxes, which } \\
\text { are considered more efficient. }\end{array}$ \\
\hline
\end{tabular}

Source. Field survey, July 2016.

\section{Conclusions and recommendations}

\subsection{Conclusions}

This study aimed at investigating how the Zambian mine fiscal regimes respond to the attributes of 'good tax' criteria. It is evident from the study that the majority (63\%) of respondents from the various sector groups constituting the mining industry disagreed that the Zambian mine tax systems respond to attributes of 'good tax' criteria. Only $23 \%$ of the respondents agreed to the responsiveness of the tax regimes to these economic perspectives dealing with; stability, neutrality, progressivity, transparency and clarity, risk sharing, equity, and economic efficiency. Based on the semi-structured interviews, most of the interviewees equally felt that the mine taxation systems fail to respond to the attributes of 'good tax' criteria. This was because of: mistrust and poor multi-stakeholder consultations between the government and the investors; lack of stabilisation agreements in the 
Chisakulo, E., \& Kambani, S.

fiscal regimes; absence of transparency and certainty; weak institutional capacities to enhance tax administration and sector monitoring; and existence of information asymmetry. The study outcome demands that the government attends to the principles of taxation in its design, formulation and implementation of the mine fiscal regimes.

\subsection{Recommendations}

Based on the results and discussions made, the following are some of the recommendations made for this study:

- Government should consider putting in place fiscal stability terms to stabilise the tax system and create growth in the mine investment environment. Fiscal stabilities grant investor confidence considering that past periods in Zambia had numerous changes made to the mine fiscal regimes.

$>$ The policymakers need to formulate and design fiscal terms that are flexible, robust and simple to ensure efficient tax administration.

$>$ Zambia should create transparency by law or through clearly published conditions in order to lessen pressures that occur due to unplanned inclusions and tax modifications that might make the fiscal regimes inequitable and inefficient.

$>$ Policymakers are expected to put in place fiscal regimes with enhanced taxation tools meant to improve mechanism to allow equitable sharing of risk between the government and investors.

$>$ Institutional capacities are essential and require to be strengthened for Zambia to tackle existing challenges in tax administration and sector monitoring so that the taxation systems respond favourably to most of the principles of good taxation.

Acknowledgement: This work was conducted as part of the studies for graduate research at University of Zambia. The authors are indebted to Copperbelt University (CBU) for financial support availed under the Special Staff Development Fellowship.

\section{References}

Adams, J., Khan, H, T, A., Raeside, R., \& White, D. (2007). Research methods for graduate business and social science students (1st ed.). New Delhi: SAGE Publication.

Africa Progress Report. (2013). Equity in extractives: Stewarding Africa's natural resource for all (pp. 63-65). Geneva, Switzerland: Africa Progress Panel.

Alba, E. M. (2009). Extractive industries value chain: An integrated approach to develop extractive industries. Extractive Industries for Development Series \# 3, African Region Working Paper, 125 (pp. 4-5).

Washington, DC: The World Bank.

Alley, C., \& Bentley, D. (2005). A remodelling of Adam Smith's tax design principles. Law papers, 45, 579-624. Retrieved from http://epublications.bond.edu.au/law_pubs/45

Andrews-Speed, C. P. (2000). Mineral and petroleum taxation, study guide. Centre for Energy, Petroleum, Mineral Law, and Policy (pp. 1.7-2.4). University of Dundee.

Baunsgaard, T. (2001). A primer on mineral taxation. International Monetary Fund, WP/01/139, (pp. 1-35). Retrieved from https://www.imf.org/external/pubs/ft/wp/2001/wp01139.pdf

Bernard, H, R. (2006). Research methods in anthropology: Qualitative and quantitative approaches (4th ed.) Oxford: AltaMira Press.

Bhattacherjee, A. (2012). Social science research: Principles, methods, and practices (2nd ed.). Textbooks Collection. Book 3. Retrieved from http://scholarcommons.usf.edu/oa_textbooks/3

Boone, Jr. H. N., \& Boone, D. A. (2012). Analysing Likert. Journal of Extension, 50(2), 1-5.

Brink, H. (1993). Validity and reliability in qualitative research. Curationis, 16(2), 35-38. https://doi.org/10.4102/curationis.v16i2.1396 
Brown, J. D. (2011). Likert items and scales of measurement? SHIKEN: Japanese Association for Language Teaching, Testing \& Evaluation SIG Newsletter, 15(1), 10 -14.

Calder, J. (2014). Administering fiscal regimes for extractive industries: A handbook (pp. 2-16). Washington, DC: International Monetary Fund.

Chisakulo, E., \& Kambani, S. (2017). Competitiveness evaluation of the Zambian mining taxation system. International Journal of Advanced Research, 5(9), 359-372. http://dx.doi.org/10.21474/IJAR01/5338

Clausing, K. A., \& Durst, M. C. (2015). A price-based royalty tax. Working paper 41, 1-22. Brighton, UK: International Centre for Tax and Development.

Collier, P. (2010). Principles of resource taxation for low-income countries. In P. Daniel, M. Keen \& C.

McPherson (Eds.), The taxation of petroleum and minerals: Principles, problems and practice (pp. 76-77). New York: Routledge.

Conrad, R. F. (2012). Zambia's mineral fiscal regime. Working Paper, 12/0653 (pp. 3-25). London: International Growth Centre.

Cooper, D. R., \& Schindler, P. (2014). Business Research Methods (12th ed.). New York: McGraw-Hill/Irwin.

Creswell, J. W., \& Miller, D. L. (2000). Determining validity in qualitative analysis. Theory into Practice, 39(3), 124-130. https://doi.org/10.1207/s15430421tip3903_2

Daniel, P., \& Sunley, M. (2010). Contractual assurances of fiscal stability. In P. Daniel, M. Keen, \& C. McPherson (Eds.), The taxation of petroleum and minerals: Principles, problems and practice (pp. 410-411). New York: Routledge.

Daniel, P., Goldsworthy, B., Maliszewski, W., Puyo, D. M., \& Watson, A. (2010). Evaluating fiscal regimes for resource projects: An example from oil development. In P. Daniel, M. Keen, \& C. McPherson (Eds.), The taxation of petroleum and minerals: Principles, problems and practice (pp. 190-194). New York: Routledge.

Das, S., \& Rose, M. (2014). Copper colonialism: British miner Vedanta KCM and the copper loot of Zambia (pp. 8-10). London: Foil Vedanta.

Dymond, A., Lambrechts, K., \& Chase, S. (2007). Undermining development: Copper mining in Zambia. Action for Southern Africa, Christian Aid, United Kingdom and Scottish Catholic International Aid Fund (pp. 6-8).

Gajigo, O., Mutambatsere, E., \& Ndiaye, G. (2012). Royalty rates in African mining revisited: Evidence from gold mining. African Economic Brief, 3(6), 1-12.

Garnaut, R., \& Ross, A. C. (1983). Taxation of mineral rents. Oxford: Clarendon Press.

Guion, L. A., Diehl, D. C., \& McDonald, D. (2011). Triangulation: Establishing the validity of qualitative studies. Institute of Food and Agricultural Sciences Extension (FCS6014) (pp. 1-3). Gainesville: University of Florida. Retrieved from http://edistt.ifas.ufl.edu/pdffiles/FY/FY39400.pdf

Guj, P., Bocoum, B., Limerick, J., Meaton, M., \& Maybee, B. (2013). How to improve mining tax administration and collection frameworks: A sourcebook (pp. 4-16). Washington, DC: World Bank and Center for Exploration Targeting. Retrieved from https://openknowledge.worldbank.org/handle/10986/16700

Harman, F., \& Guj, P. (2013). Mineral taxation and royalties. In Mineral economics monograph 29 (2nd ed., pp. 92-213). Victoria, Australia: Australian Institute of Mining and Metallurgy.

Hogan, L. (2008). International minerals taxation: Experiences and issues. In the Conference Paper Proceedings (pp. 27-28). Canberra, Australia: Australian Bureau of Agricultural and Resource Economics.

International Council of Mining and Metals [ICMM]. (2014). Enhancing mining's contribution to the Zambian economy and society (pp. 39-51). Mining: Partnerships for Development. Chamber of Mines of Zambia and ICMM.

International Council on Mining and Metals [ICMM]. (2009). The challenge of mineral wealth: Using resource endowments to foster sustainable development. Commonwealth Secretariat (pp. 35-58). Retrieved from https://www.icmm.com

Korinek, J. (2013). Mineral resource trade in Chile: Contribution to development and policy implications. $O E C D$ Trade Policy Papers 145 (pp. 20-22). OECD Publishing. http://dx.doi.org/10.1787/5k4bw6twpf24-en

Kumar, R. (1991). Taxation of a cyclical industry. Resources Policy, 17(2), 133-148. 
Chisakulo, E., \& Kambani, S.

https://doi.org/10.1016/0301-4207(91)90037-V

Kumar, R. (2011). Research methodology: A step-by step guide for beginners (3rd ed.). London: SAGE, Publications, Inc.

Land, D. (2009). Capturing a fair share of fiscal benefits in the extractive industry. Transnational Corporations, 18(1), 157-173. https://doi.org/10.18356/1f2a726f-en

Leech, N. L., Barrett, K. C., \& Morgan, G. A. (2005). SPSS for intermediate statistics: Use and interpretation (2nd ed.). New Jersey: Lawrence Erlbaum Associates, Inc.

Lundstøl, O., Raballand, G., \& Nyirongo, F. (2013). Low government revenue from the mining sector in Zambia and Tanzania: Fiscal design, technical capacity or political will? ICTD Working Paper 9 (pp. 30-32). Brighton: International Centre for Tax and Development (ICTD)/Institute of Development Studies.

Lungu, J. (2009). The politics of reforming Zambia's mining tax regime. Southern Africa Resource Watch, Resource Insight, 8, 15-19.

Lusaka Times. (2015). Zambia's inconsistent mining taxation policy is costing us. Retrieved from https://www.lusakatimes.com

Mackey, A., \& Gass, S, M. (2005). Second language research; Methodology and design (1st ed.). New Jersey: Lawrence Erlbaum Associates, Inc.

Manley, D. (2012). Caught in the trap: Zambia's mineral tax reforms. ICTD Working Paper 5 (pp.1-28). Brighton: International Centre for Tax and Development (ICTD)/Institute of Development Studies. https://doi.org/10.2139/ssrn.2408591

Manley, D. (2013). A guide to mining taxation in Zambia (pp. 20-32). Lusaka: Zambia Institute for Policy Analysis and Research. Retrieved from http://www.zipar.org.zm

Mineral Resources Development Policy [MRDP]. (2013). Mineral resource development policy (pp. 1-13). Ministry of Mines, Energy and Water Development. Republic of Zambia.

Minnitt, R. C. A., \& Cawood, F. T. (1999). Information as an alternative to mineral rights taxation. Journal of the South African Institute of Mining and Metallurgy, 99(6), 341-350.

Nakhle, C. (2008). Petroleum taxation: Sharing the oil wealth - a study of petroleum taxation yesterday, today and tomorrow (pp. 7-15). London: Taylor and Francis Group. https://doi.org/10.4324/9780203927892

Nakhle, C. (2010). Petroleum fiscal regimes: Evolution and challenges. In P. Daniel, M. Keen, \& C. McPherson (Eds.), The taxation of petroleum and minerals: Principles, problems and practice (pp. 114-115). New York: Routledge.

Natural Resource Charter [NRC]. (2014). Natural resource charter: Precept 4, fiscal regimes and contract terms. Technical guide. Retrieved from http://www.resourcegovernance.org

Natural Resource Governance Institute [NRGI]. (2015). Fiscal regime design: What revenues the government will be entitled to collect (pp. 1-7). Retrieved from https://resourcegovernance.org/sites/default/files/nrgi_Fiscal-Regime-Design.pdf

Nellen, A. M. (2002). The AICPA's 10 guiding principles. The Tax Adviser 33.2 (pp. 100-107). Retrieved from http://scholarworks.sjsu.edu

Otto, J. M. (2007). Competitive position of Mongolia's mineral sector fiscal system: The case of a model copper mine (pp. 27-28). North America-Mongolia Business Council Inc.

Otto, J., \& Cordes, J. (2002). The regulation of mineral enterprises: A global perspective on economics, law and policy (pp. 8-40). Westminster, Colorado: Rocky Mountain Mineral Law Foundation.

Otto, J., Andrews, C., Cawood, F., Dogget, M., Guj, P., Stermole, F., Stermole, J., \& Tilton, J. (2006). Mining royalties: A global study of their impact on investors, government, and civil society. Directions in Development, Energy and Mining. Washington, DC: World Bank. https://doi.org/10.1596/978-0-8213-6502-1

PriceWaterhouseCoopers [PWC]. (2015). Weathering the Storm, Zambia's 2016 national budget (pp. 23-24). Retrieved from http://www.pwc.com/zm/en/publications/zambia-national-budget-2016.html

Saunders, M., Lewis, P., \& Thornhill, A. (2009). Research methods for business students (5th ed.). Essex: Pearson Education Limited.

Simpasa, A., Hailu, D., Levine, S., \& Tibana, R.J. (2013). Capturing mineral revenues in Zambia: Past trends 
and future prospects. United Nations Development Program and EU-UN Global Partnership on Land. Natural Resources and Conflict. Retrieved from http://www.undp.org/

Smith, A. (1776). An inquiry into the nature and causes of the wealth of nations. Indianapolis: Liberty Classics Edition of 1981.

Times of Zambia. (2015). Copper benefits still elusive. Business Times, 17(111), 9-10.

Tissot, R. (2010). Challenges of designing an optimal petroleum fiscal model in Latin America. Energy Working Paper (pp. 4-5). Washington, DC: Inter-American Development Bank.

United Nations Conference on Trade and Development [UNCTAD]. (2007). World investment report: Transnational corporation, extractive industries and development (pp. 166-167). New York and Geneva: United Nations. Retrieved from http://unctad.org/en/docs/wir2007_en.pdf

World Bank (2015). Making mining work for Zambia. The economic, health, and environmental nexus of Zambia's copper mining economy. Zambia Economic Brief, Issue 5, 17-35. Washington, DC: World Bank Group. Retrieved from https://openknowledge.worldbank.org/handle/10986/22039

Zambia Development Agency [ZDA]. (2011). Zambia's investor guide handbook (pp. 16-17). Lusaka: Zambia Development Agency (ZDA).

Zambia Extractive Industries Transparency Initiative [ZEITI]. (2014). Fifth reconciliation report based on the financial year 2012 (pp. 18-19). Lusaka, Zambia: Moore Stephens.

Zambia Extractive Industries Transparency Initiative [ZEITI]. (2015). Eighth report for the fiscal year ended $31^{\text {st }}$ December, 2015 (pp. 69-70). Lusaka, Zambia: BDO.

Zikmund, W. G., Babin, B. J., Carr, J. C., \& Griffin, M. (2009). Business research methods (8th ed., pp. 306-308). Cengage Learning. 
Chisakulo, E., \& Kambani, S. 